\title{
Microplankton composition off NW Iberia at the end of the upwelling season: source areas of harmful dinoflagellate blooms
}

\author{
B. G. Crespo*, I. G. Teixeira, F. G. Figueiras, C. G. Castro \\ Instituto de Investigacións Mariñas, CSIC, Eduardo Cabello 6, Vigo 36208, Spain
}

\begin{abstract}
The Rías Baixas of Galicia are 4 bays on the NW Iberia Peninsula that experience harmful dinoflagellate blooms toward the end of the upwelling season, in late summer to early autumn. In order to identify the source areas of initial bloom populations, we studied the hydrographic regime and the microplankton composition in the NW Iberian margin at the end of summer 1991. Three distinctive oceanographic features were recognised as possible sources of initial populations: (1) the onset of a northward stream, the Iberian Poleward Current (IPC), which can transport seed populations to the region; (2) a subsurface chlorophyll maximum (SCM); and (3) weak upwelling at the coast, which can promote the growth of dinoflagellates. While the SCM held populations of the small dinoflagellates Heterocapsa niei and Prorocentrum minimum, larger dinoflagellates Prorocentrum micans, Dinophysis acuminata, Gymnodinium catenatum and the raphidophycean Heterosigma akashiwo, which habitually form blooms in the Rías Baixas, were only found in upwelled coastal waters, mostly off the Rías. These species occurred with a microplankton assemblage composed of other large dinoflagellates and diatoms, which is characteristic of the final summer upwelling events in the Rías. It is hypothesised that the Rías Baixas can be both the source and the target of harmful dinoflagellate blooms. Summer upwelling, through cyst resuspension and subsequent germination in the nearby stratified waters, would provide the initial populations. Downwelling, which promotes the accumulation of dinoflagellates in the interior of the Rías, would ensure blooms and hence replenish the sediments with new cysts.
\end{abstract}

KEY WORDS: Harmful dinoflagellates · Coastal upwelling $\cdot$ Iberian Poleward Current · Subsurface chlorophyll maximum $\cdot$ NW Iberia $\cdot$ Rías Baixas

\section{INTRODUCTION}

Harmful algal blooms (HABs) in coastal waters may be responsible for important human diseases and frequently have negative effects on the fisheries and aquaculture of affected regions. The need to mitigate the deleterious effects of HABs has prompted a large amount of research in several coastal areas (e.g. Figueiras et al. 1994, Tester \& Steidinger 1997, Pitcher et al. 1998, Anderson et al. 2005a), from which we have learned much about the dynamics of these blooms. Still, the initiation phase remains one of the least understood aspects of HAB dynamics. This is because HABs, like other phytoplankton blooms, initi- ate from a very small or hidden population, which often escapes detection. Furthermore, blooms and their source areas can be separated by large distances in coastal regions with strong advective processes (Tester \& Steidinger 1997, Anderson et al. 2005a). As a consequence, HABs are normally detected, and therefore studied, once the bloom has developed and affected the coastal zone. Nevertheless, research specifically planned to look for source populations suggests that cyst resuspension from sediments and their germination might deliver the seed population required for bloom initiation into the water column (Anderson et al. 2005b). It has also been reported that initial populations may be hidden in thin subsurface 
layers (Rines et al. 2002) or fronts (Pitcher et al. 1998, Anderson et al. 2005a), from where they can develop into blooms under suitable environmental and biological conditions (Pingree et al. 1975, Bjørnsen \& Nielsen 1991, Kononen et al. 2003). Since the location of seed populations varies among regions, source area detection for initial populations of HABs is needed in different coastal regions to advance the understanding of bloom dynamics and, thus, advance the mitigation of their negative effects.

The Rías Baixas are 4 bays on the NW Iberian Peninsula (Fig. 1a), one the of most important sources of
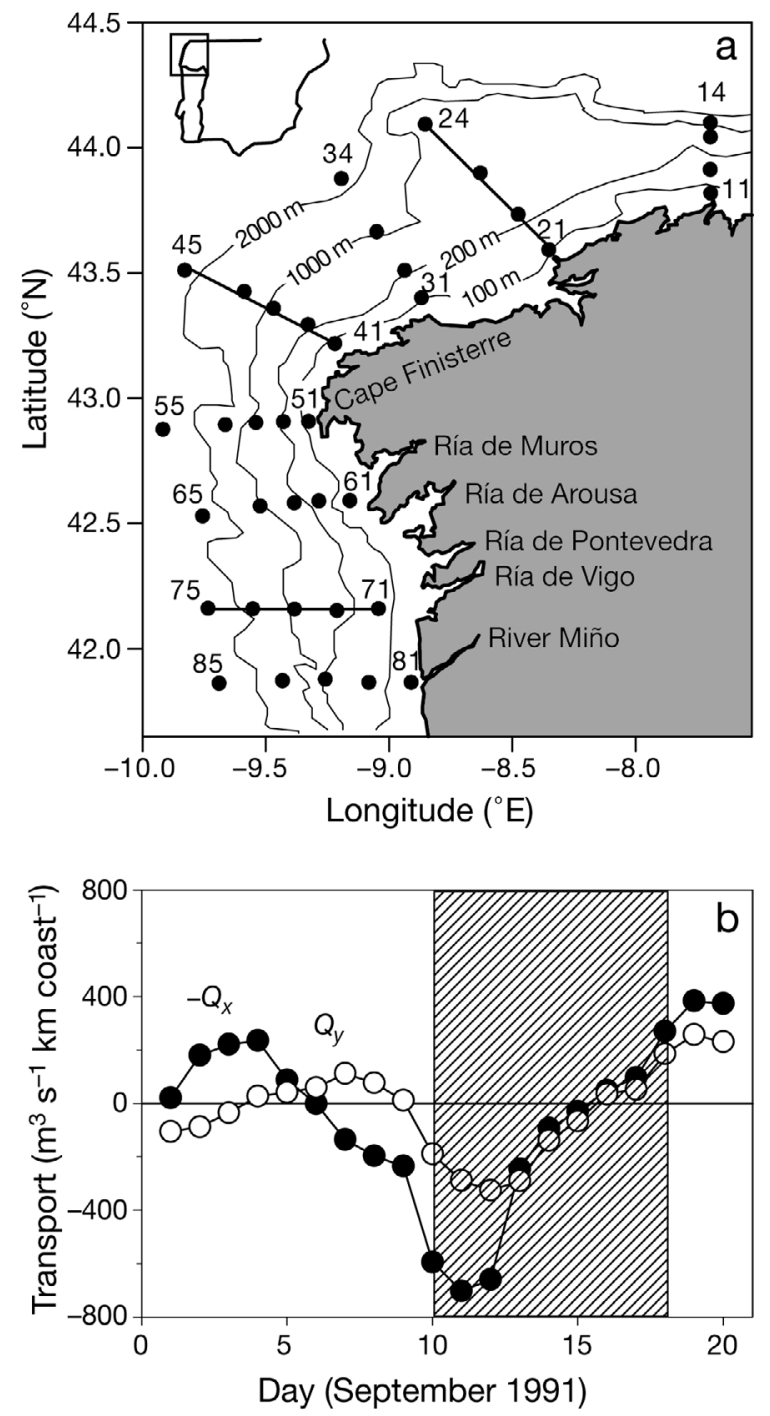

Fig. 1. (a) Sampled region in the NW Iberian margin showing the 4 Rías Baixas, the river Miño and the transects selected for vertical representations (Stns 21 to 24,51 to 55 and 71 to 75 ) in Figs. 4, 6 \& 8. (b) Ekman transport components, $-Q_{\mathrm{X}}$ (crossshore transport) and $Q_{Y}$ (along-shore transport), from September 1 to 20,1991 , calculated at $43^{\circ} \mathrm{N}, 11^{\circ} \mathrm{W}$. Dashed area denotes the sampling period mussel production in the world and the most productive in Europe (Figueiras et al. 2002). In these bays, harmful dinoflagellate blooms are recurrent at the end of the upwelling season (Fraga et al. 1988, Figueiras et al. 1994). Seasonal upwelling-downwelling is one of the most characteristic features of the NW Iberia region. Northerly winds induce coastal upwelling from spring to autumn, whereas southerly winds favour downwelling in winter (Wooster et al. 1976). The seasonal upwelling-downwelling transition coincides with the onset of the Iberian Poleward Currrent (IPC) (Álvarez-Salgado et al. 2003, Torres \& Barton 2006), a surface northward flow on a slope that originates from the advection of warm and saline oceanic water (Frouin et al. 1990, Peliz et al. 2005). During this transition, when upwelling subsides but downwelling is not yet strongly established and the water column is stratified, a subsurface chlorophyll maximum (SCM) is commonly observed on the shelf and in the open ocean (Castro et al. 1997, Torres \& Barton 2006). Upwelling and downwelling also determine the circulation of the Rías (Figueiras et al. 2002, Piedracoba et al. 2005). During upwelling, the Rías show a surface outflow that exports microplankton to the shelf. This outgoing flow is compensated by an inflow of coastal upwelled water at the bottom, which supplies nutrients into the Rías. The circulation reverses during downwelling, when surface water from the shelf enters the Rías and the outflow towards the shelf occurs through the bottom. Upwelling promotes the dominance of diatoms in the Rías (Figueiras \& Ríos 1993) and on the shelf (Rodríguez et al. 2006), but dinoflagellates gradually gain more importance over the season, reaching their highest abundances at the end of summer (Margalef 1958, Figueiras \& Ríos 1993, Crespo et al. 2006). HABs in the Rías during the seasonal upwelling-downwelling transition are related to the reverse circulation imposed by downwelling, which causes the accumulation of dinoflagellates (Fraga et al. 1988, Figueiras et al. 1994, Crespo et al. 2006). Although some evidence indicates that initial populations for these blooms come from local dinoflagellate populations in the Rías and the neighbouring shelf (Figueiras et al. 1994, Crespo et al. 2006), it has also been suggested that the IPC could be the source (Fraga et al. 1988, Sordo et al. 2001). The role the SCM may play as a source of initial populations for HABs in the region has never been explored.

In the present study, we studied the microplankton composition and the hydrographic regime in the NW Iberian margin during the seasonal upwelling-downwelling transition of 1991, when harmful blooms did not occur, but dinoflagellates were important components of the microplankton community. The objective was to identify the source areas of initial populations for harmful dinoflagellate blooms in the Rías. 


\section{MATERIALS AND METHODS}

Sampling. A total of 37 stations, located along 8 transects perpendicular to the shoreline on the northwestern Iberian margin (Fig. 1a), were sampled at the end of the summer in 1991 (September 10 to 18) on board the RV 'Investigador-S'. Sampling was conducted with a conductivity-temperature-depth (CTD) probe equipped with a fluorometer and a rosette with 12 PVC Niskin bottles, which was lowered to the bottom at all stations. Water samples for determinations of nitrate and chlorophyll a (chl a) concentrations and microplankton abundance were collected from the CTD upcasts at several depths, from surface to bottom on the shelf and from surface to $100-150 \mathrm{~m}$ at the oceanic stations. The depths were selected after inspecting the fluorescence profiles to ensure that the SCM was sampled. Sampling began at the northernmost transect, Stns 11 to 14 , and finished at the southernmost transect, Stns 81 to 85 (Fig. 1a).

Ekman transport and dynamic topography. The Ekman transport components perpendicular $\left(Q_{\mathrm{X}}\right)$ and parallel $\left(Q_{y}\right)$ to the western coast were estimated using the magnitude and direction of the wind off Cape Finisterre $\left(43^{\circ} \mathrm{N}, 11^{\circ} \mathrm{W}\right)$ deduced from surface pressure charts (Wooster et al. 1976):

$$
Q_{x, y}=\frac{\rho_{\mathrm{a}} C_{\mathrm{d}}|V| V_{Y, X}}{f \rho_{\mathrm{sw}}}
$$

where $\rho_{\mathrm{a}}$ is the air density, $C_{\mathrm{d}}$ is an empirical drag coefficient $\left(1.3 \times 10^{-3}\right.$, dimensionless), $\mathbf{V}_{X, Y}$ is the vector of the wind speed $|V|$ estimated at the sea surface, $f$ is the Coriolis parameter at $43^{\circ} \mathrm{N}\left(9.946 \times 10^{-5} \mathrm{~s}^{-1}\right)$ and $\rho_{\mathrm{sw}}$ is the seawater density (ca. $1025 \mathrm{~kg} \mathrm{~m}^{-3}$ ). Therefore, $Q_{X}$ and $Q_{Y}$ are related to north-south and east-west winds, respectively. The sign of $Q_{X}$ was changed to associate positive values with offshore transport (upwelling) of surface waters at the western coast (Fig. 1b). Upwelling at the northern coast is related to easterly winds.

The geostrophic flow in the upper layer was estimated from dynamic topography calculated relative to $300 \mathrm{~m}$. This reference level was chosen following Frouin et al. (1990) as a level of small motion compared to the surface circulation. Computations for shallower stations on the shelf were done using the extrapolation method of Reid \& Mantyla (1976), which uses the specific volume anomaly from the nearest pair of deeper oceanic stations. Therefore, our estimates must be considered a qualitative description of the geostrophic circulation.

Nitrate and chl a. Nitrate $\left(\mu \mathrm{mol} \mathrm{kg}^{-1}\right)$ was determined on board using a segmented flow analysis system (Technicon AAII) by reduction to nitrite following the Hansen \& Grasshoff (1983) method with some modifications (Mouriño \& Fraga 1985).
For chl a $\left(\mathrm{mg} \mathrm{m}^{-3}\right), 100 \mathrm{ml}$ of seawater were filtered under low vacuum pressure through $25 \mathrm{~mm}$ Whatman $\mathrm{GF} / \mathrm{F}$ filters. The filters were immediately frozen at $-20^{\circ} \mathrm{C}$ for at least $24 \mathrm{~h}$ until pigments were extracted in $90 \%$ acetone over $24 \mathrm{~h}$ in the dark at $4^{\circ} \mathrm{C}$. Readings were made with a Turner Designs fluorometer calibrated with pure chl a (Sigma).

Microplankton. Samples of $100 \mathrm{ml}$, preserved in Lugol's idone solution, were allowed to settle in composite sedimentation chambers and the organisms were counted and identified to the species level, when possible, using an inverted microscope. Two transects were scanned at $\times 400$ and $\times 250$ to enumerate the small species. The larger species, often less abundant, were counted from scanning the whole slide at $\times 100$.

Assemblages within the microplankton community were distinguished using principal component analysis (PCA), which also allowed the reduction of the information contained in the original list of species abundance. The analysis was made with the correlation matrix of abundances after they were transformed to $\log (x+1)$, where $x=$ cells per $100 \mathrm{ml}$, to reduce and homogenise variance. Since double 0 values in the matrix can distort the results, they were partially removed by including in the analysis only those species or groups present in at least $20 \%$ of the samples. This provided a starting matrix of 60 species $\times 282$ samples.

\section{RESULTS}

\section{Meteorological and hydrographic conditions}

Winds, and hence the Ekman transport components, were highly variable in September 1991 (Fig. 1b). At the beginning of September, weak northerly winds favourable for upwelling shifted to southwesterly on September 5, leading to a strong downwelling $\left(-Q_{X}=\right.$ $-595 \mathrm{~m}^{3} \mathrm{~s}^{-1} \mathrm{~km}^{-1} ; Q_{Y}=-190 \mathrm{~m}^{3} \mathrm{~s}^{-1} \mathrm{~km}^{-1}$ ) at the start of the cruise on September 10. After 3 d, downwelling began to subside, and at the end of the cruise on September 18, weak northeasterly winds induced upwelling again $\left(Q_{X}=270 \mathrm{~m}^{3} \mathrm{~s}^{-1} \mathrm{~km}^{-1} Q_{y}=185 \mathrm{~m}^{3} \mathrm{~s}^{-1}\right.$ $\mathrm{km}^{-1}$ ).

The dynamic topography at sea surface (Fig. 2a) revealed the coastward advection of oceanic water, which diverged into poleward and southward flows north and south of $42.5^{\circ} \mathrm{N}$, respectively. The geostrophic poleward flow on the slope at 43 to $43.5^{\circ} \mathrm{N}$ (ca. $24 \mathrm{~cm} \mathrm{~s}^{-1}$ ) was stronger than the southward flow at $42^{\circ} \mathrm{N}$ (ca. $4.5 \mathrm{~cm} \mathrm{~s}^{-1}$ ), and this change in flow direction and velocity coincided with the relaxation of wind stress and the change from southerly to northerly winds that occurred during the sampling period 


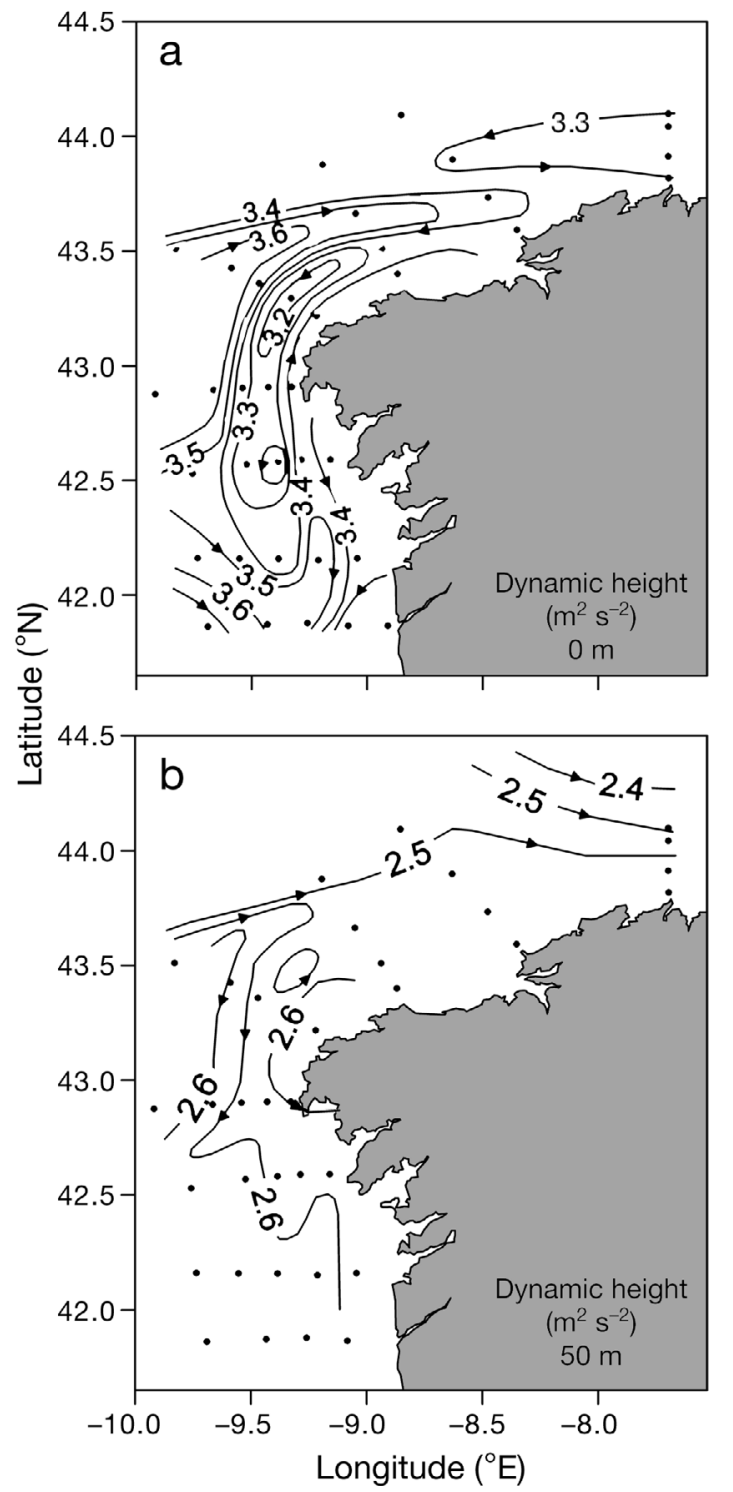

Fig. 2. Distributions of the dynamic height at (a) the surface and (b) $50 \mathrm{~m}$ depth

(Fig. 1b). The poleward flow turned eastward at ca. $43.5^{\circ} \mathrm{N}$ to converge on the shelf with an opposite flow from the east. A weak divergence existed over the shelf between 42.0 and $43.5^{\circ} \mathrm{N}$. The poleward flow, although weaker, was also evident at $50 \mathrm{~m}$ deep (Fig. 2b), where the divergence on the shelf was perceptible in the vicinity of Cape Finisterre. The advected oceanic water, warmer $\left(>20^{\circ} \mathrm{C}\right.$, Fig. 3a) and saltier ( $>35.7$, Fig. $3 b$ ) than shelf waters, favoured the development of a surface salinity front on the southern shelf, confining the less saline coastal waters from the Rías and the river Miño (Fig. 3b).

The vertical distributions of temperature (Figs. $4 \mathrm{a}-\mathrm{c}$ ) showed a strong stratified water column, but also depicted a weak upwelling caused by the divergence on the shelf (Fig. 4b). The sinking at the adjacent oceanic Stn 44 was caused by the advection of warm $\left(>20^{\circ} \mathrm{C}\right)$ oceanic water (Fig. $\left.4 \mathrm{~b}\right)$. The salinity profiles (Figs. $4 \mathrm{~d}-\mathrm{f}$ ) revealed the presence of a high salinity core $(>35.7)$ below $50 \mathrm{~m}$. The core, which was saltier $(>35.9)$ in the south (Fig. 4f) than in the north $(<35.9)$ (Figs. $4 \mathrm{~d} \& \mathrm{e}$ ), surfaced at the ocean side of the southernmost transects (Fig. 4f), leaving the less saline coastal waters confined in a stratified surface layer on the shelf. The advection and sinking of surface oceanic water also caused the separation of the subsurface salinity maximum into 2 cores, one on the shelf and the other offshore, at the transect of Stns 41 to 45 (Fig. 4e).

\section{Nitrate and chl a}

Nitrate concentrations were very low at sea surface $\left(<0.1 \mu \mathrm{mol} \mathrm{kg}{ }^{-1}\right)$ (Fig. 3c). Concentrations $>0.1 \mu \mathrm{mol}$ $\mathrm{kg}^{-1}$ were only found at very few stations on the shelf,

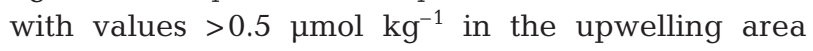
north of Cape Finisterre. The highest concentrations $\left(>4 \mu \mathrm{mol} \mathrm{kg}^{-1}\right.$ ) were registered at the mouth of river Miño, although they quickly fell to $<0.1 \mu \mathrm{mol} \mathrm{kg}{ }^{-1}$ within a short distance from the coast. However, the entire region showed a well-developed nitracline at ca. $50 \mathrm{~m}$ (Figs. $4 \mathrm{~g}-\mathrm{i}$ ), which surfaced on the shelf in the upwelling area (Fig. 4h).

The highest surface chl a concentrations $\left(>2 \mathrm{mg} \mathrm{m}^{-3}\right)$ were located on the western shelf off the Rías Baixas (Fig. 3d), where the less saline coastal waters were confined (Fig. 3b). The lowest chl a concentrations $\left(<0.1 \mathrm{mg} \mathrm{m}^{-3}\right)$ corresponded to the advected oceanic water, while the rest of the shelf stations had intermediate values (ca. $0.5 \mathrm{mg} \mathrm{m}^{-3}$ ). Associated with the nitracline was a SCM (Figs. $4 \mathrm{j}-1$ ), as revealed by the significant positive relationship between the depths of the maximum chl $a$ values and the depths with nitrate concentration of $1 \mu \mathrm{mol} \mathrm{kg}{ }^{-1}\left(\mathrm{r}^{2}=0.83, \mathrm{~m}=1.06 \pm 0.08\right.$, $\mathrm{p}<0.001)$. Whereas the nitracline and the SCM surfaced on the shelf in the upwelling area (Figs. $4 \mathrm{~h} \& \mathrm{k}$ ), the high chl a concentrations in the surface waters on the southern shelf (Fig. 4l) did not correspond to a comparable surfacing of the nitracline (Fig. 4i), which points to the advection of phytoplankton from the Rías.

\section{Microplankton abundance and distribution}

The microplankton community was dominated by small flagellates and dinoflagellates, accounting for $55 \pm 15 \%$ and $35 \pm 14 \%$ of the total cell abundance, respectively. Among dinoflagellates, the small species Heterocapsa niei, Gymnodinium spp. $<20 \mu \mathrm{m}$ and Prorocentrum minimum were dominant, representing 


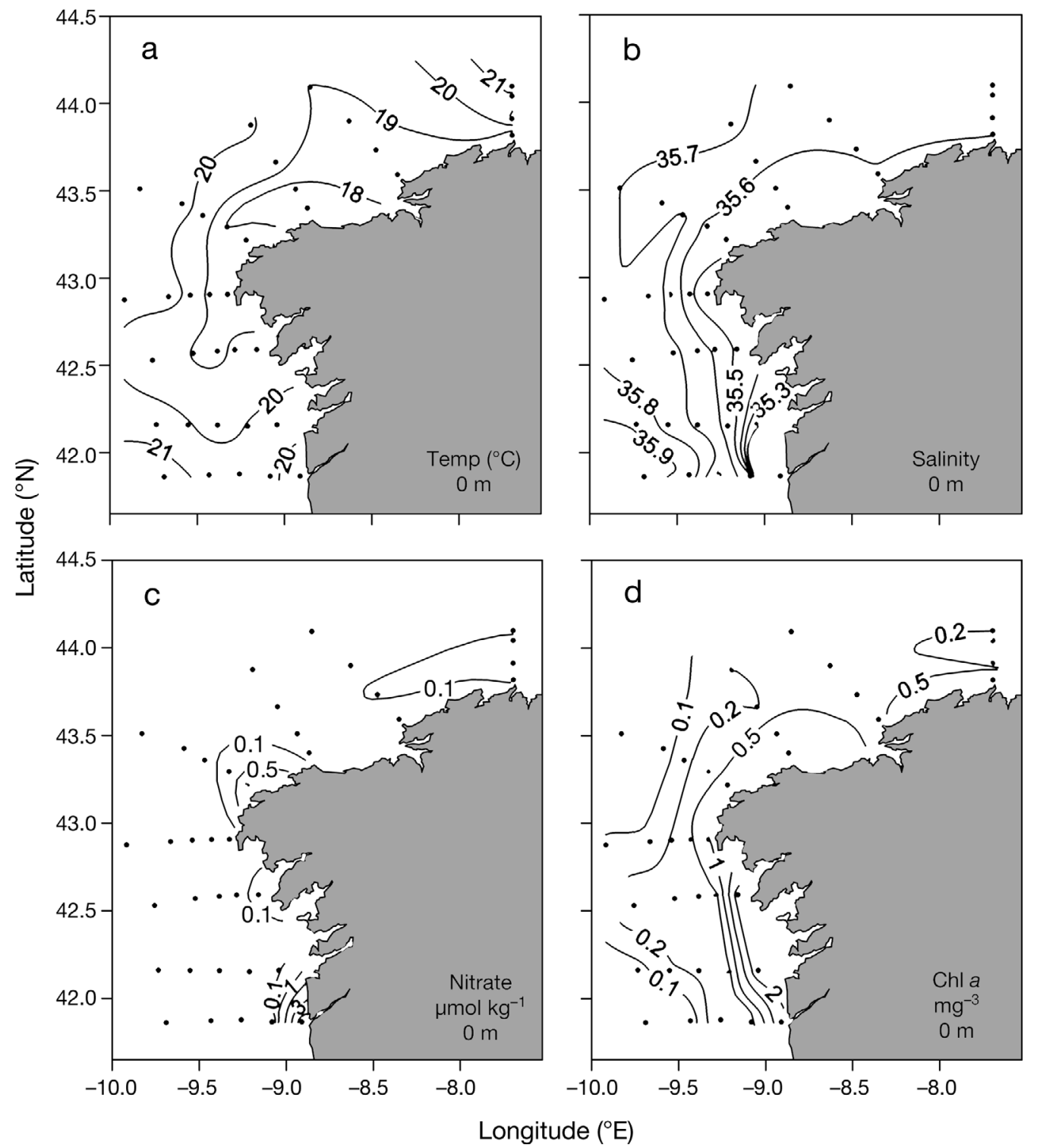

Fig. 3. Surface distributions of (a) temperature, (b) salinity, (c) nitrate concentration and (d) chl a concentration in the sampled region

$87 \pm 9 \%$ of the total dinoflagellate abundance. Diatoms $(7 \pm 12 \%)$ and ciliates $(3 \pm 3 \%)$ accounted for only a minor fraction of the total microplankton abundance.

The total cell abundance and the abundance of diatoms, dinoflagellates and small flagellates at the surface decreased from the coast to the open ocean (Figs. 5a-d). The highest cell abundance was recorded in the surface waters off the Rías Baixas (Figs. 5a \& 6c), coinciding with the highest chl a concentrations (Figs. 3d \& 41). Microplankton abundance at the surface of Stn $71\left(4.2 \times 10^{3}\right.$ cells $\left.\mathrm{ml}^{-1}\right)$ was 30 times higher than the mean cell abundance $\left(1.4 \pm 2.8 \times 10^{2}\right.$ cells ml $\left.{ }^{-1}\right)$ in the sampled area. Diatoms (Figs. 5b \& 6f) also attained high importance $\left(2.5 \times 10^{3}\right.$ cells $\left.\mathrm{ml}^{-1}\right)$, where they accounted for $60 \%$ of the total microplankton abundance with Skeletonema cf. costatum, comprising the bulk $(95 \%)$ of the population. Diatom abundance at this location was 120 times higher than the mean diatom abundance in the sampled area $(21 \pm 159$ cells $\mathrm{ml}^{-1}$ ). Dinoflagellates (Figs. 5c \& 6i), small flagellates (Figs. 5d \& 6l) and ciliates (data not shown) also had their highest abundances in front of the Rías (606, 1023 and 23 cells $\mathrm{ml}^{-1}$ for dinoflagellates, small flagellates and ciliates, respectively), 14, 15 and 7 times higher than their corresponding mean abundances. Heterocapsa niei accounted for $81 \%$ of the total dinoflagellate abundance at this location. The lowest microplankton abundance corresponded to the advected oceanic 

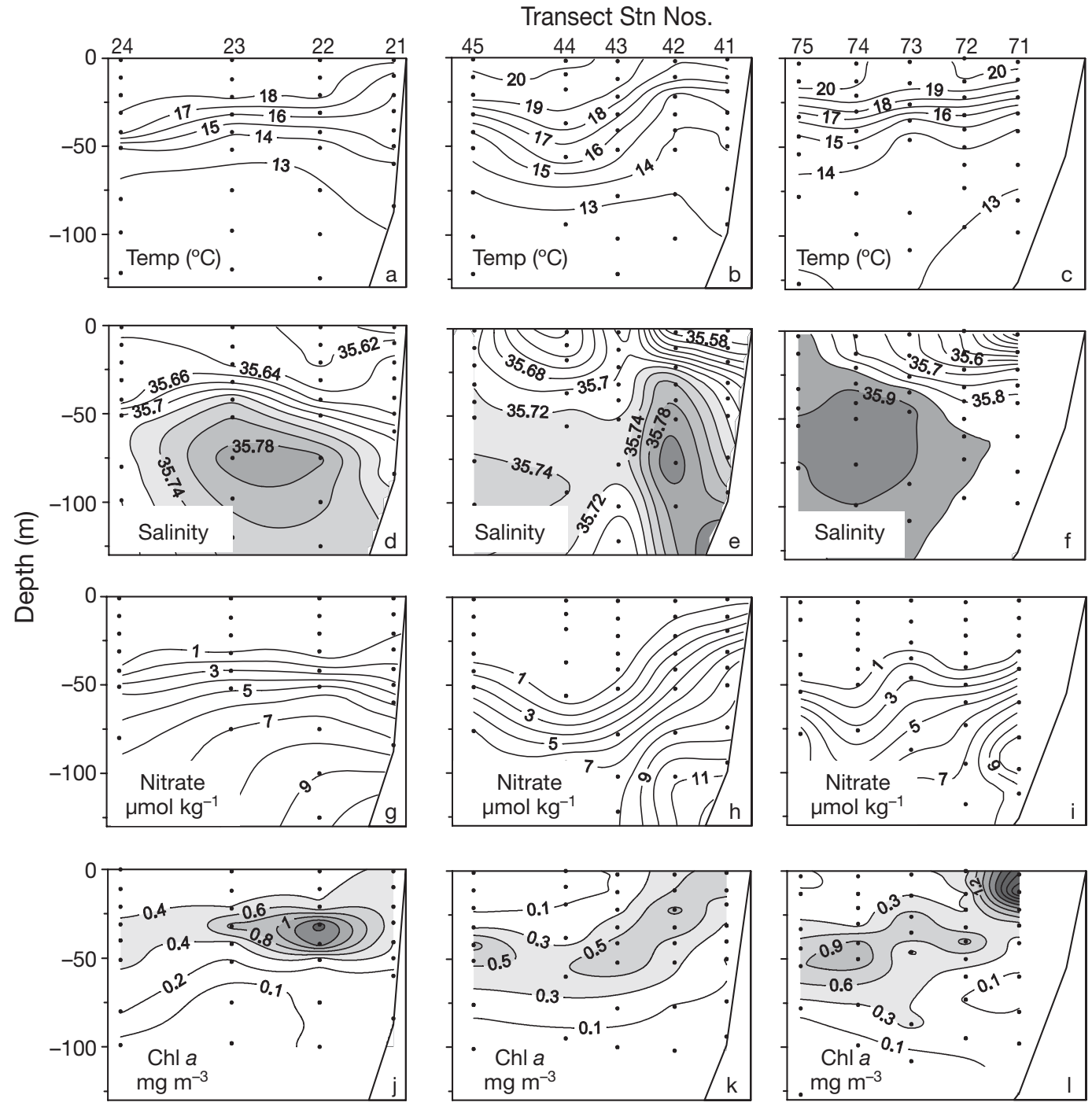

Fig. 4. Vertical distributions at the 3 selected transects (Stns 21 to 24,51 to 55 and 71 to 75 , see Fig. 1a) of (a to c) temperature, (d to f) salinity, ( $g$ to i) nitrate and ( $\mathrm{j}$ to $\mathrm{l}$ ) chl a concentrations

water (Fig. 5a), where small flagellates and small dinoflagellates represented $>90 \%$ of the total cell abundance. Diatoms were especially scarce $(<5$ cells $\mathrm{ml}^{-1}$ ) in these surface oceanic waters (Fig. 5b).

While diatoms were practically confined to coastal waters (Figs. 5b \& 6d-f), dinoflagellates and small flagellates extended their presence to oceanic waters, where they contributed to form the SCM (Figs. 6g-1). Small species, including unidentified flagellates, Cryptophyceae spp. and Heterocapsa niei, accounted for ca. $80 \%$ of the total microplankton at the SCM. The contribution of Heterocapsa niei was particularly significant $(>25 \%)$ at the SCMs of Stns 22, 23 and 45 (Figs. 4j-k \& 6g-h). Prorocentrum minimum, though less important $(19 \%)$, also contributed to the SCM at Stn 22 at $30 \mathrm{~m}$.

\section{Microplankton assemblages}

Two components, which explained $21 \%$ of the total variance in the original data set, were extracted by PCA. The first principal component (PC1) explained $14 \%$ of the total variance and the second (PC2) accounted for $7 \%$. Among the 60 species or groups considered, only 4 (medium-sized naked dinoflagellates, small Gyrodinium spp., small Dinophysis sp. and small Coscinodiscus sp.) had low negative loads with PC1 (Table 1). This load ordination and the positive correlations of the component scores with the logarithm of the total cell abundance ( $r=0.86, p<0.001)$, and the logarithm of the abundance of flagellates $(\mathrm{r}=$ 0.79, $\mathrm{p}<0.001)$ and dinoflagellates $(\mathrm{r}=0.79, \mathrm{p}<$ 0.001), indicated that PC1 explained the variability 


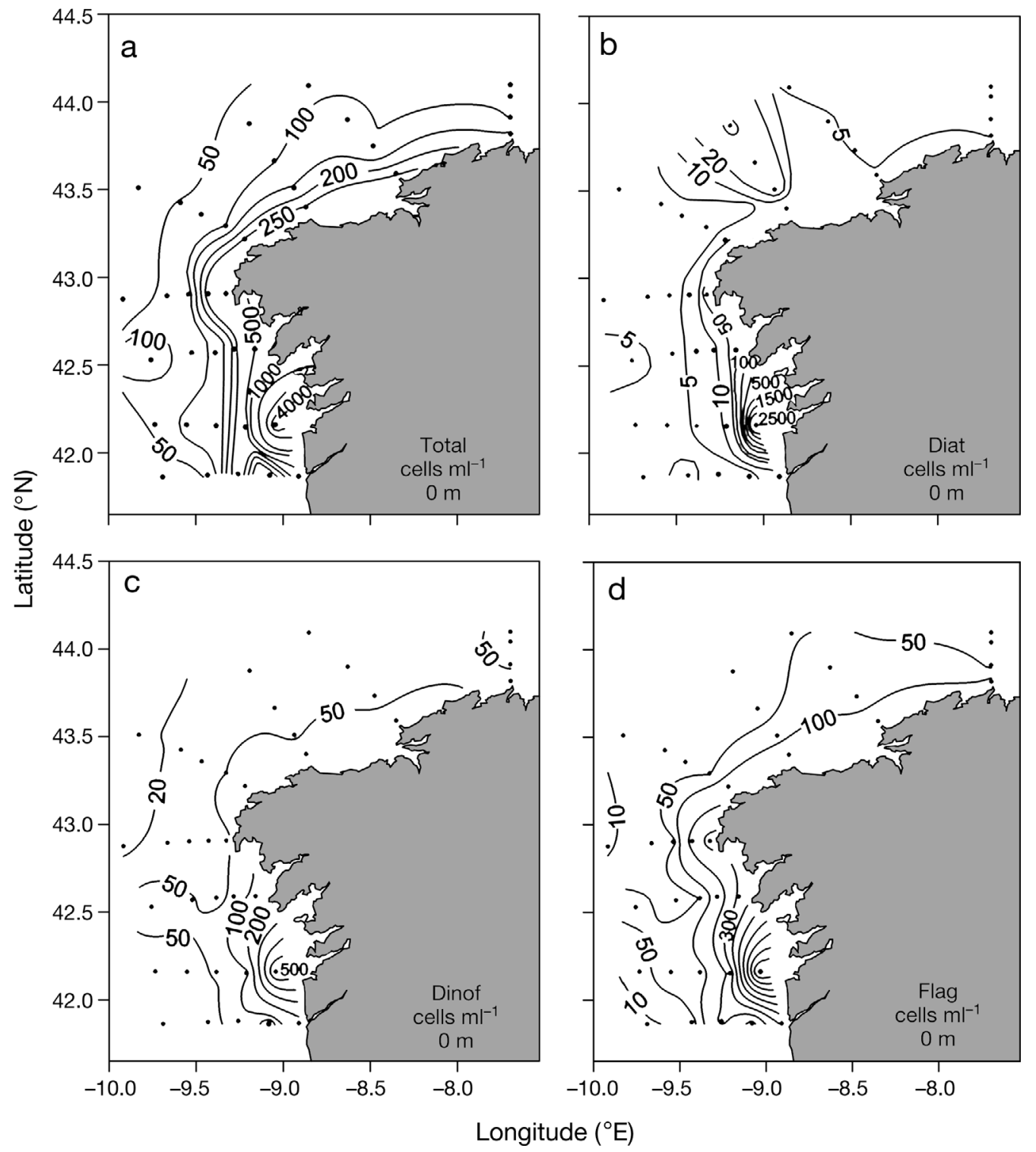

Fig. 5. Surface distributions of abundance of (a) total microplankton, (b) diatoms, (c) dinoflagellates and (d) flagellates other than dinoflagellates

related to changes in microplankton abundance. Consequently, the distributions of the PC1 scores at the surface (Fig. 7a) showed a coastal-ocean gradient, with the highest positive values on the shelf in front of the Rías Baixas and negative values associated with the advected oceanic water. Negative values of PC1 were also detected at deeper layers at the transects of Stns 41 to 45 and 71 to 75 (Figs. 8b \& c), coinciding with the higher influence of advected oceanic water (Figs. 4b,c, e,f). To some extent, PC1 also included the variability attributed to changes in cell abundance at the SCMs (Figs. 6a-c \& 8a-c). Thus, the high PC1 score (1.5) at Stn 22 at $30 \mathrm{~m}$ (Fig. 8a) corresponded with the high cell abundance (Fig. 6a) of dinoflagel- lates (Fig. 6g) and small flagellates (Fig. 6j). A weaker agreement between PC1 score distributions and cell abundance was found on the other transects (Figs. 6b $\& 8 b)$. This was due to the almost exclusive dominance of a few species (small flagellates [58\%] and Heterocapsa niei [22\%] at Stn 42 at $75 \mathrm{~m}$ ) or to the dominance of species not included in PCA (Chaetoceros socialis [58\%] at Stn 42 at $40 \mathrm{~m}$ ) because of their presence in very few samples.

The PC2 differentiated between an assemblage (positive loads, Table 1) composed of the large dinoflagellates Goniodoma polyedricum, Prorocentrum compressum, the small dinoflagellates Prorocentrum balticum, P. minimum, Gymnodinium spp. 

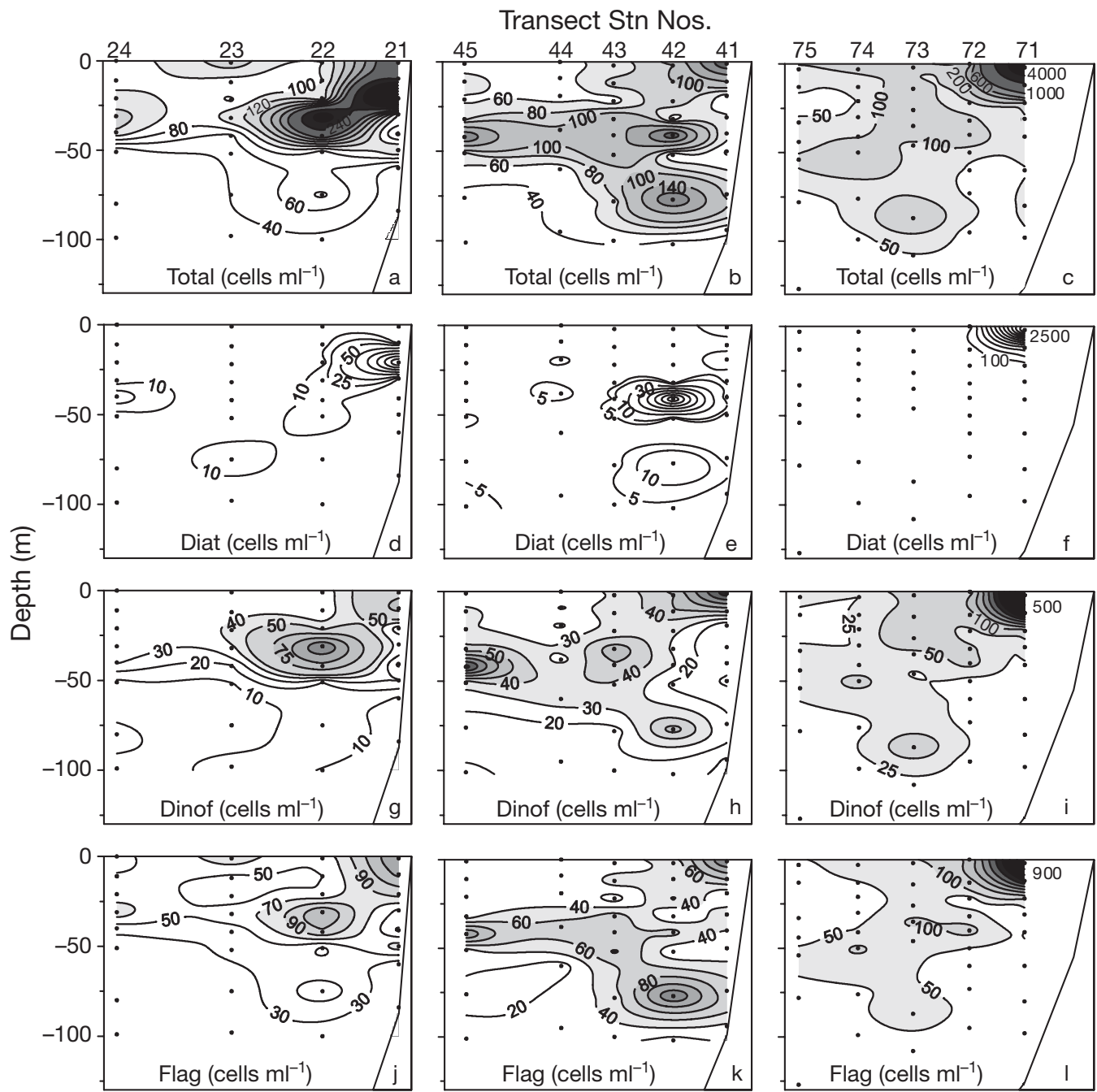

Fig. 6. Vertical distributions at the 3 selected transects (Stns 21 to 24,51 to 55 and 71 to 75, see Fig. 1a) of abundance of (a to c) total microplankton, ( $\mathrm{d}$ to $\mathrm{f}$ ) diatoms, ( $\mathrm{g}$ to i) dinoflagellates and ( $\mathrm{j}$ to $\mathrm{l}$ ) flagellates other than dinoflagellates

$<20 \mu \mathrm{m}$, and ciliates Strombidium cf. compressum, $S$. strobilum, S. ovale, and another assemblage (negative loads, Table 1) containing the diatoms Proboscia alata, Leptocylindrus minimus, Thalassiosira rotula and Pseudo-nitzschia cf. seriata, the large and medium-sized dinoflagellates Ceratium fusus and Torodinium robustum, respectively, the phototrophic ciliate Mesodinium rubrum and the flagellate Solenicola setigera. Negative scores of this component were restricted to coastal waters (Figs. $7 b$ \& $8 d-f$ ), with the highest negative values on the southernmost shelf in front of the Rías Baixas. Although all oceanic stations had positive PC2 scores (Figs.7b \& 8d-f), the highest positive scores were found at the stations closest to the shelf (Figs. 8d-f). Positive scores $<1$ (Figs. $7 b$ \& $8 \mathrm{e}, \mathrm{f})$ were associated with the advected oceanic water (Figs. 3a,b \& 4b,c,e,f).

\section{Distribution of species that cause harmful blooms in the Rías}

The dinoflagellates Dinophysis acuminata and Gymnodinium catenatum and the raphidophycean Heterosigma akashiwo regularly cause harmful blooms in the Rías at the end of the upwelling season. The harmless dinoflagellate Prorocentrum micans frequently accompanies these blooms. Although not included in the PCA due to their presence in a limited number of samples, these species were recorded during the sampling, and we have examined their distributions. The presence of the 4 species was restricted to surface coastal waters, with $P$. micans, $H$. akashiwo and $D$. acuminata found exclusively off the Rías (Figs. 9a-c). G. catenatum, also located off the Rías, had an additional centre of distribution in the 
Table 1. Correlation coefficients (loads) of the species and taxa selected for Principal Component Analysis (PCA) with the 2 principal components. Species and taxa ordered according to PC1. Bold: highest positive loads for PC2; bold italic: highest negative loads. Species grouped in diatoms (Diat), dinoflagellates (Dinof), other flagellates than dinoflagellates (Flag) and ciliates (Cil)

\begin{tabular}{|c|c|c|c|}
\hline Group & Taxon & PC1 & PC2 \\
\hline Flag & Cryptophyceae spp. & 0.778 & 0.161 \\
\hline Flag & Unidentified small flagellates $(<10 \mu \mathrm{m})$ & 0.753 & -0.111 \\
\hline Dinof & Heterocapsa niei & 0.712 & 0.261 \\
\hline Dinof & Scrippsiella trochoidea & 0.583 & -0.185 \\
\hline Dinof & Protoperidinium spp. (cysts) & 0.567 & -0.261 \\
\hline Cil & Strombidium ovale & 0.559 & 0.400 \\
\hline Cil & Strombidium cornutum & 0.551 & 0.169 \\
\hline Cil & Mesodinium pulex & 0.544 & -0.182 \\
\hline Dinof & Prorocentrum minimum & 0.537 & 0.324 \\
\hline Dinof & Phalacroma rotundatum & 0.523 & -0.235 \\
\hline Cil & Strombidium turbo & 0.522 & 0.164 \\
\hline Cil & Mesodinium rubrum & 0.494 & -0.332 \\
\hline Cil & Strombidium sp. (small, $<20 \mu \mathrm{m})$ & 0.481 & 0.214 \\
\hline Dinof & Protoperidinium pyriforme & 0.478 & -0.221 \\
\hline Cil & Strombidium delicatissimum & 0.476 & -0.070 \\
\hline Dinof & Protoperidinium depressum & 0.473 & -0.226 \\
\hline Cil & Lohmanniella spiralis & 0.469 & 0.127 \\
\hline Dinof & Ceratium fusus & 0.457 & -0.342 \\
\hline Cil & Strombidium cf. sulcatum & 0.457 & 0.181 \\
\hline Cil & Tontonia gracillima & 0.457 & 0.089 \\
\hline Dinof & Ceratium horridum & 0.449 & -0.102 \\
\hline Diat & Proboscia alata & 0.442 & -0.352 \\
\hline Dinof & Gymnodinium agiliforme & 0.434 & 0.235 \\
\hline Dinof & Prorocentrum micans & 0.419 & -0.030 \\
\hline Dinof & Gymnodinium sp. (small, $<20 \mu \mathrm{m}$ ) & 0.405 & 0.393 \\
\hline Dinof & Cochlodinium helix & 0.398 & -0.161 \\
\hline Dinof & Amphidinium flagellans & 0.366 & -0.282 \\
\hline Dinof & Protoperidinium brevipes & 0.335 & -0.090 \\
\hline Dinof & Gymnodinium nanum & 0.322 & 0.254 \\
\hline Dinof & Ceratium macroceros & 0.320 & 0.272 \\
\hline Dinof & Amphidinium cf. flagellans (small, $<20 \mu \mathrm{m}$ ) & 0.305 & -0.101 \\
\hline Diat & Leptocylindrus minimus & 0.290 & -0.340 \\
\hline Diat & Thalassiosira nana & 0.255 & 0.050 \\
\hline Dinof & Torodinium robustum & 0.248 & -0.301 \\
\hline Dinof & Ceratium furca & 0.247 & 0.101 \\
\hline Dinof & Gyrodinium varians & 0.245 & 0.089 \\
\hline Diat & Pseudo-nitzschia cf. seriata & 0.240 & -0.291 \\
\hline Diat & Centric diatom (small, $<20 \mu$ ) & 0.238 & -0.164 \\
\hline Cil & Strombidium cf. compressum & 0.234 & 0.436 \\
\hline Diat & Thalassionema nitzschioides & 0.233 & -0.242 \\
\hline Flag & Solenicola setigera & 0.224 & -0.506 \\
\hline Dinof & Oxytoxum variabile & 0.220 & 0.226 \\
\hline Dinof & Oxytoxum sphaeroideum & 0.219 & -0.135 \\
\hline Cil & Strombidium strobilum & 0.214 & 0.423 \\
\hline Dinof & Protoperidinium cerasus & 0.211 & -0.286 \\
\hline Dinof & Prorocentrum balticum & 0.209 & 0.464 \\
\hline Flag & Leucocryptos spp. & 0.202 & 0.153 \\
\hline Dinof & Goniodoma polyedricum & 0.166 & 0.586 \\
\hline Dinof & Gymnodinium spp.(medium, 20 to $40 \mu \mathrm{m})$ & 0.164 & 0.065 \\
\hline Diat & Thalassiosira rotula & 0.162 & -0.308 \\
\hline Diat & Chaetoceros spp. Small & 0.151 & 0.105 \\
\hline Cil & Strombidium spp. (medium, са. $30 \mu \mathrm{m}$ ) & 0.120 & 0.152 \\
\hline Flag & Dictyocha octonaria & 0.099 & -0.208 \\
\hline Dinof & Gyrodinium fusiforme & 0.086 & -0.132 \\
\hline Dinof & Naked dinoflagellate spp. (small, $<20 \mu \mathrm{m}$ ) & 0.072 & 0.055 \\
\hline Dinof & Prorocentrum compressum & 0.034 & 0.404 \\
\hline Dinof & Naked dinoflagellate spp. (medium, 20-40 $\mu \mathrm{m}$ ) & -0.003 & 0.085 \\
\hline Dinof & Gyrodinium spp.(small, $<20 \mu \mathrm{m})$ & -0.063 & 0.296 \\
\hline Dinof & Dinophysis sp.(small) & -0.095 & 0.030 \\
\hline Diat & Coscinodiscus sp.(small) & -0.157 & -0.155 \\
\hline
\end{tabular}

upwelling area north of Cape Finisterre (Fig. 9d). The 4 species showed significant positive and negative correlations with the PC1 and PC2 scores, respectively (Table 2 ).

\section{DISCUSSION}

The meteorological and hydrographic conditions recorded during this cruise were typical for the time of seasonal upwelling-downwelling transition in the NW Iberia, which is characterised by a variable wind regime, the onset of the IPC and the existence of vestiges of coastal upwelling (Álvarez-Salgado et al. 2003, Torres \& Barton 2006). As previously reported, the IPC in the NW Iberia occurred through the advection to the western shelf of warm and saline surface oceanic water that turned eastwards at $43^{\circ} \mathrm{N}$ following the coastline (Torres \& Barton 2006). In fact, the large-scale meridional density gradient in the NE Atlantic forces the eastward advection of subtropical oceanic water at ca. 39 to $40^{\circ} \mathrm{N}$ (Frouin et al. 1990, Peliz et al. 2005, Crespo \& Figueiras 2007), which subsequently results in the northward flow characteristic of the IPC (Frouin et al. 1990, Haynes \& Barton 1990, ÁlvarezSalgado et al. 2003). However, local winds modulate the location of the IPC and the flow velocity, with southwesterly winds favouring its position on the shelf and enhancing the northward velocity, and northeasterly winds forcing its displacement to the open ocean and sometimes reversing the flow direction. Consequently, under variable wind conditions, like those occurring at the end of summer and beginning of autumn (Fig. 1b), hydrographic features that simultaneously define upwelling and the IPC are frequently observed in the NW Iberian margin (Castro et al. 1997). In this case, upwelling was perceptible in the weak divergence near Cape Finisterre (Figs. 2a,b, 3c \& 4b,h), but was especially obvious in the outflow of low saline waters (Fig. 3b) with elevated 

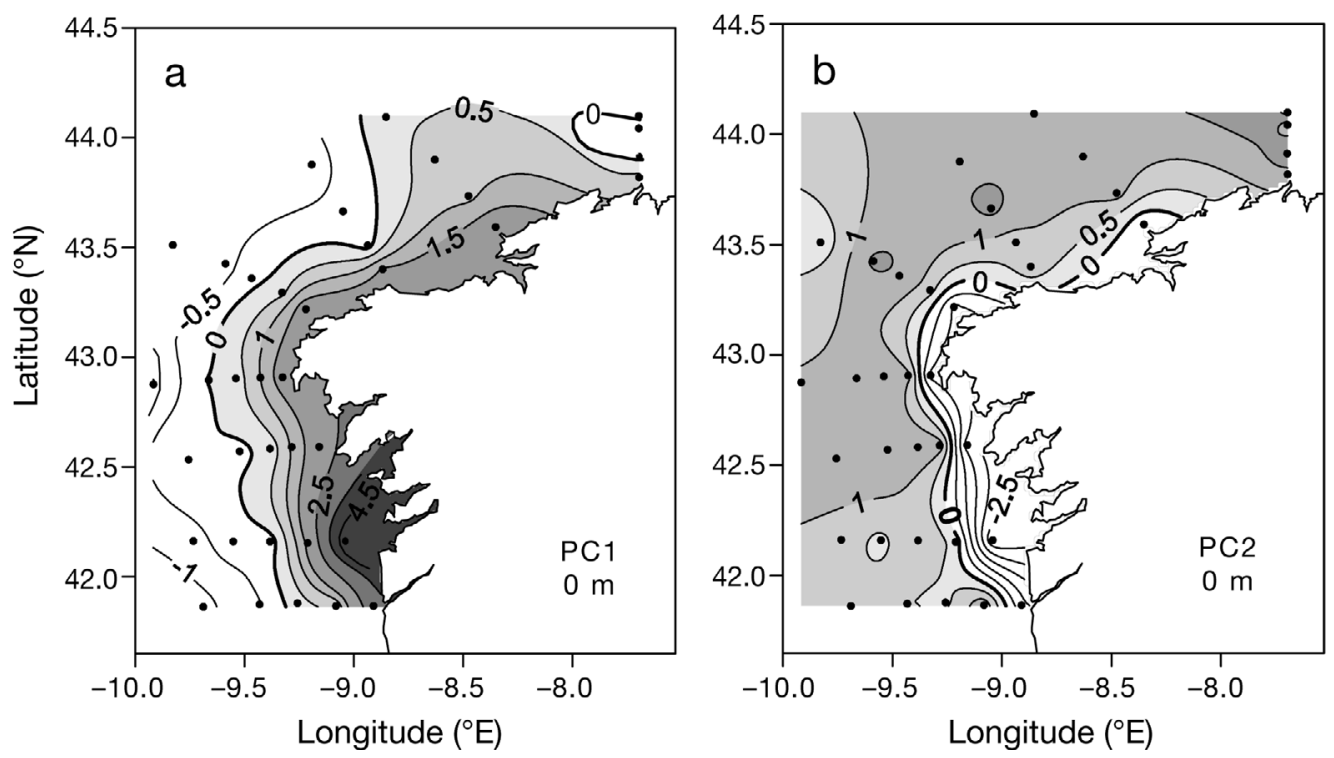

Fig. 7. Surface distributions of (a) PC1 and (b) PC2 scores extracted by the PCA of microplankton species abundance

chl a concentrations (Fig. 3d) and high microplankton abundance (Fig. 5a-d) from the Rías. These outwelled waters, which result from the positive estuarine circulation of the Rías imposed by upwelling (Figueiras et al. 2002, Piedracoba et al. 2005), were retained on the nearest shelf because the IPC prevented their export to the open ocean. The lack of continuity of the poleward flow further north (Figs. 2a \& b) indicates the weakness and recent formation of the IPC (Castro et al. 1997, Álvarez-Salgado et al. 2003, Torres \& Barton 2006). The absence of a homogeneous mixed layer (Figs. 4a-c), characteristic of well-developed IPCs, also points to a newly formed IPC (Álvarez-Salgado et al. 2003). The presence of a subsurface salinity maxi- mum near the slope, which becomes fresher and deeper northwards (Figs. 4d-f), is considered a confirmation of the existence of the poleward flow slope (Frouin et al. 1990, Torres \& Barton 2006).

Surface waters with low nutrient and chl a concentrations (Figs. 3c \& d), low microplankton abundance (Figs. 5 \& 7a), and an SCM at ca. $50 \mathrm{~m}$ associated with the nitracline (Figs. $4 \mathrm{~g}-1$ ) are oceanographic features that are regularly recorded when the IPC develops in the region (Castro et al. 1997, Torres \& Barton 2006, Crespo \& Figueiras 2007). As on other occasions (Castro et al. 1997, Crespo \& Figueiras 2007), the SCM was composed of small species, mainly small flagellates, with lower concentrations of the
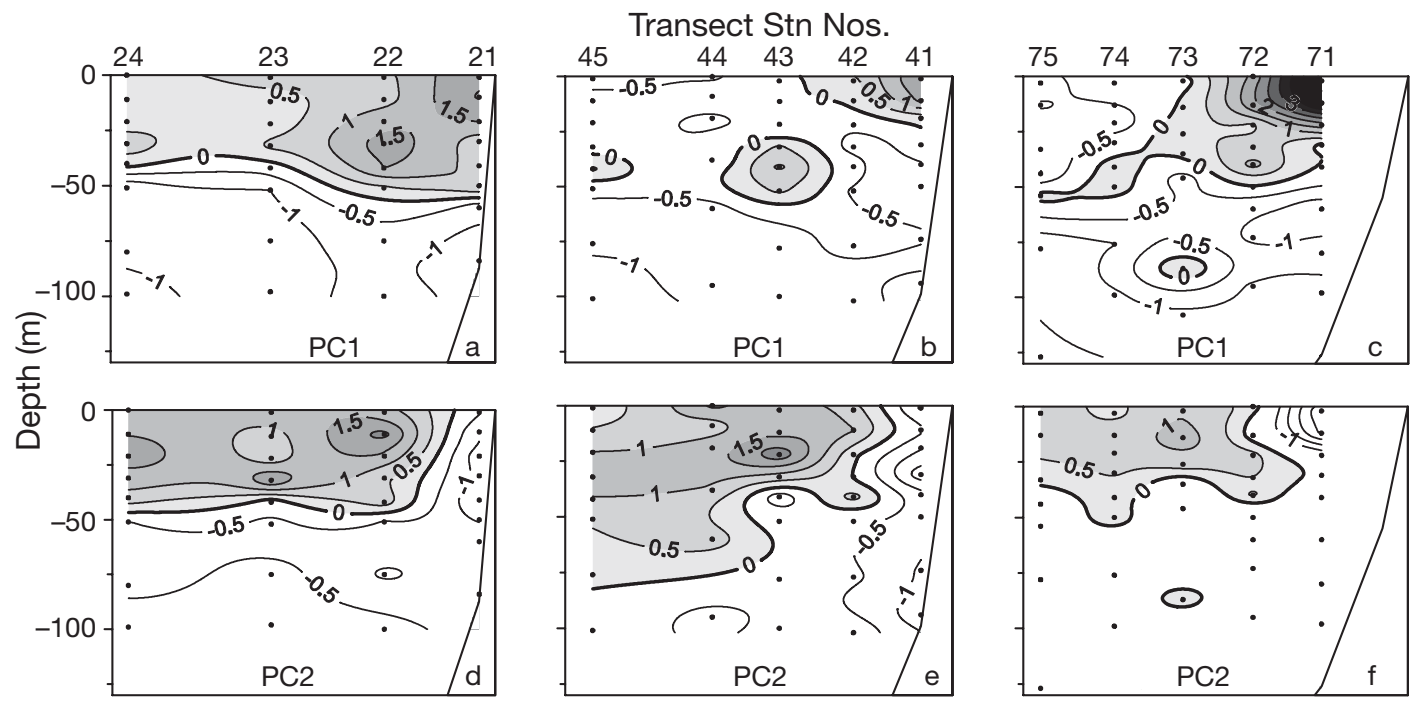

Fig. 8. Vertical distributions at the 3 selected transects (Stns 21 to 24,51 to 55 and 71 to 75 , see Fig. 1a) of (a to c) PC1 and (d to f) PC2 scores extracted by the PCA of microplankton species abundance 


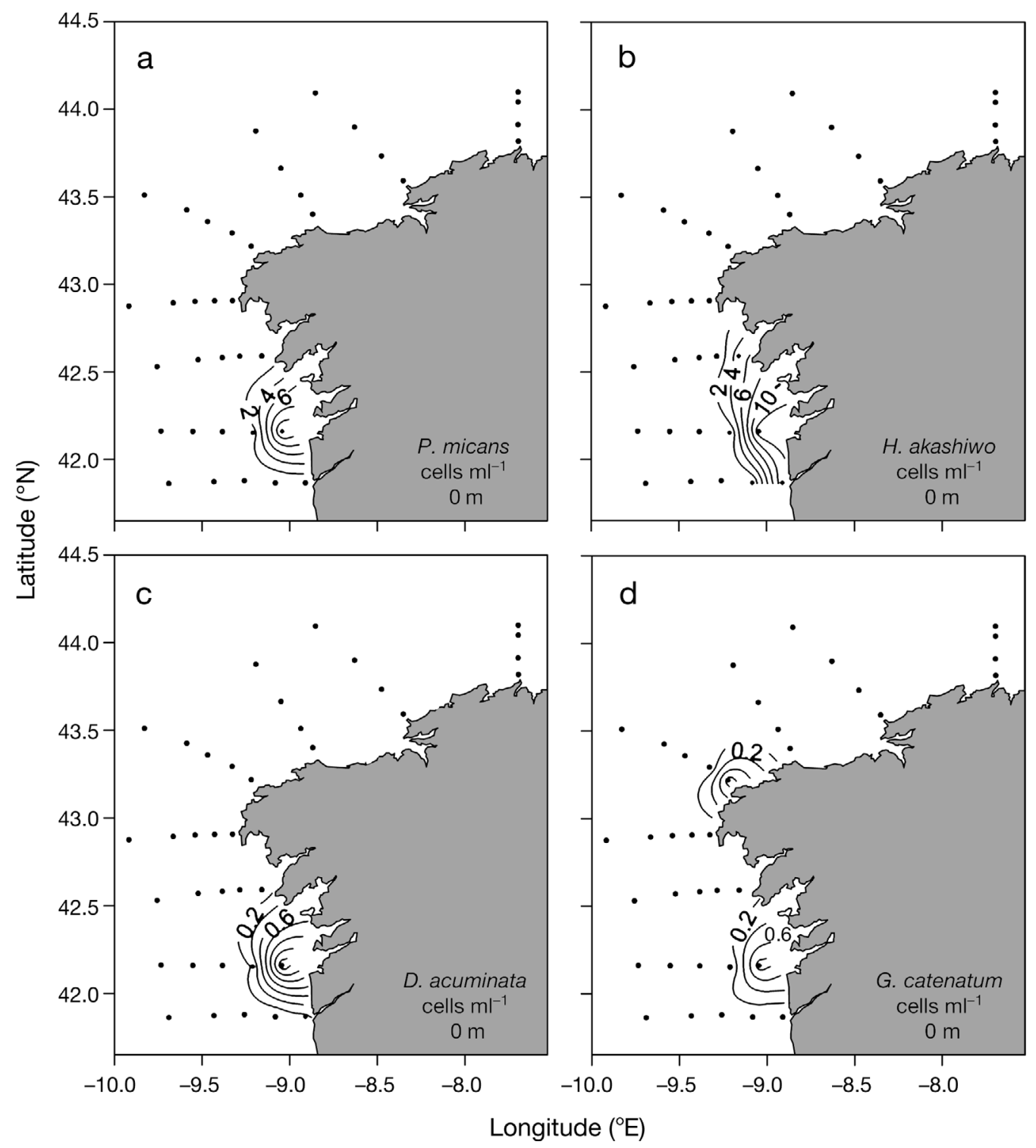

Fig. 9. Surface distributions of the abundance of (a) Prorocentrum micans, (b) Heterosigma akashiwo, (c) Dinophysis acuminata and (d) Gymnodinium catenatum. The last 3 species regularly cause harmful blooms in the Rías Baixas at the end of the upwelling season, while $P$. micans is an accompanying species

small dinoflagellates Heterocapsa niei and Prorocentrum minimum at some places. Large dinoflagellates, specifically those that cause harmful blooms in the Rías Baixas, were found in coastal surface waters, mostly off the Rías but also in the upwelling area of Cape Finisterre (Fig. 9). Thus, these harmful species occurred in areas with high microplankton abundance (Figs. 5 \& 7a) associated with an assemblage (Fig. 7b, Table 2) composed of large diatoms and the large dinoflagellates Ceratium fusus and Torodinium robustum (negative values of PC2, Table 1), characteristic of the final summer upwelling events in the Rías Baixas (Margalef 1958, Figueiras \& Ríos 1993, Crespo et al. 2006).
The IPC reported here, like other IPCs (Castro et al. 1997, Crespo \& Figueiras 2007), showed very low microplankton abundance with a dominance of small flagellates and small dinoflagellates and an absence of the large dinoflagellates that form recurrent blooms in the Rías. Therefore, its role as a source of the initial populations for harmful dinoflagellate blooms can be discarded. However, the onset of the IPC must be seen as an oceanographic process that prevents the export and hence, the dispersion of the initial populations into the open ocean, thus contributing to the development of HABs in the Rías.

While the role of SCM as a source area cannot be totally ruled out, because Heterocapsa niei and Proro- 
Table 2. Correlation coefficients $(\mathrm{p}<0.001, \mathrm{n}=37$ ) between the logarithm of the abundance of Prorocentrum micans and 3 species that cause harmful blooms in the Rías Baixas at the end of the upwelling season, and the scores of PC1 and PC2 in the surface layer

\begin{tabular}{|lcc|}
\hline Species & PC1 & PC2 \\
\hline Prorocentrum micans & 0.66 & -0.61 \\
Heterosigma akashiwo & 0.71 & -0.68 \\
Dinophysis acuminata & 0.73 & -0.68 \\
Gymnodinium catenatum & 0.53 & -0.59 \\
\hline
\end{tabular}

centrum minimum were found at some locations and high concentrations of small (Kononen et al. 2003) and large harmful species (Pingree et al. 1975, Bjørnsen \& Nielsen 1991) have been found in other SCMs, our results suggest that the main source of initial populations for HABs are the upwelled waters. The Rías Baixas could be especially relevant in this respect, since upwelling is intensified in their interiors. Their bathymetry, with lower depths in their inner sections, favours the intrusion and uplift of coastal subsurface upwelled waters during weak upwelling events that are not strong enough to cause surface signals on the continental shelf. In this sense, the Rías could be both the source and the target of the most serious harmful episodes, owing to the interaction between microplankton succession and circulation. From previous work in the region it is now well known that diatoms dominate in spring and during strong summer upwelling events, while dinoflagellates, among which harmful species are common, become important components of the microplankton community in summer (Margalef 1958, Figueiras \& Ríos 1993, Crespo et al. 2006). Microplankton also show a distinctive spatial distribution during summer upwelling, with higher abundance of diatoms near the coast and/or in the inner part of the Rías, where upwelling is stronger, while dinoflagellates are more important in the nearby stratified oceanic/shelf waters (Tilstone et al. 1994). The inflow of upwelled waters at the bottom might resuspend cysts from the sediments, which can germinate while being transported towards the near shelf by the surface outflow of the positive estuarine circulation. Upwelling relaxation and/or the IPC would reintroduce into the Rías the dinoflagellates previously exported to the shelf, which under appropriate downwelling conditions could result in a harmful bloom (Figueiras et al. 1994, Fermín et al. 1996). In this way, the Rías Baixas could be the 'incubator' (sensu Anderson et al. 2005b) of harmful dinoflagellate blooms in the area, with summer upwelling providing the initial populations and the downwelling forced by the IPC ensuring blooms and the formation of new cysts.
Acknowledgements. We are grateful to the members of the Oceanography group at the Instituto de Investigacións Mariñas for their help. We also thank 3 anonymous reviewers for their critical and helpful comments. Financial support for this work came from the EU projects MAST-CT90-0017 (The control of phytoplankton dominance) and HABILE (EVK3-CT2001-00063). B.G.C. was funded by a CSIC-ESF I3P fellowship and I.G.T by a FCT (Portuguese Foundation for Science and Technology) doctoral fellowship. This is a contribution to the GEOHAB Core Research Project - HABs in upwelling systems.

\section{LITERATURE CITED}

Álvarez-Salgado XA, Figueiras FG, Pérez FF, Groom S and others (2003) The Portugal coastal counter current off NW Spain: new insights on its biogeochemical variability. Prog Oceanogr 56:281-321

Anderson DM, Keafer BA, Geyer WR, Signell RP, Loder TC (2005a) Toxic Alexandrium blooms in the western Gulf of Maine: the plume advection hypothesis revisited. Limnol Oceanogr 50:328-345

Anderson DM, Stock CA, Keafer BA, Nelson AB, Thompson B, McGillicuddy DJ, Keller M, Matrai PA, Marin J (2005b) Alexandrium fundyense cyst dynamics in the Gulf of Maine. Deep-Sea Res II 52:2522-2542

Bjørnsen PK, Nielsen TG (1991) Decimeter scale heterogeneity in the plankton during a pycnocline bloom of Gyrodinium aureolum. Mar Ecol Prog Ser 73:263-267

Castro CG, Álvarez-Salgado XA, Figueiras FG, Pérez FF, Fraga F (1997) Transient hydrographic and chemical conditions affecting microplankton populations in the coastal transition zone of the Iberian upwelling system (NW Spain) in September 1986. J Mar Res 55:321-352

Crespo BG, Figueiras FG (2007) A spring poleward current and its influence on microplankton assemblages and harmful dinoflagellates on the western Iberian coast. Harmful Algae 6:686-699

Crespo BG, Figueiras FG, Porras P, Teixeira IG (2006) Downwelling and dominance of autochthonous dinoflagellates in the NW Iberian margin: the example of the Ría de Vigo. Harmful Algae 5:770-781

Fermín EG, Figueiras FG, Arbones B, Villarino ML (1996) Short-timescale development of a Gymnodinium catenatum population in the Ría de Vigo (NW Spain). J Phycol 32: 212-221

Figueiras FG, Ríos AF (1993) Phytoplankton succession, red tides and the hydrographic regime in the Rías Bajas of Galicia. In: Smayda TJ, Shimizu Y (eds) Toxic phytoplankton blooms in the sea. Elsevier, New York, p 239-244

Figueiras FG, Jones KJ, Mosquera AM, Álvarez-Salgado XA, Edwards A, MacDougall N (1994) Red tide assemblage formation in an estuarine upwelling ecosystem: Ría de Vigo. J Plankton Res 16:857-878

Figueiras FG, Labarta U, Fernández Reiriz MJ (2002) Coastal upwelling, primary production and mussel growth in the Rías Baixas of Galicia. Hydrobiologia 484:121-131

Fraga S, Anderson DM, Bravo I, Reguera B, Steidinger KA, Yentsch CM (1988) Influence of upwelling relaxation on dinoflagellates and shellfish toxicity in Ría de Vigo, Spain. Estuar Coast Shelf Sci 27:349-361

Frouin R, Fiúza AFG, Ambar I, Boyd TJ (1990) Observations of a poleward surface current off the coasts of Portugal and Spain during winter. J Geophys Res 95(C1):679-691 Hansen H, Grasshoff K (1983) Automated chemical analysis. 
In: Grasshoff K, Ehrardt M, Kremling K (eds), Methods of seawater analysis. Verlag Chemie, Weinheim, p 347-395

Haynes R, Barton ED (1990) A poleward flow along the Atlantic coast of the Iberian Peninsula. J Geophys Res 95: 11425-11441

Kononen K, Huttunen M, Hällfors S, Gentien P and others (2003) Development of a deep chlorophyll maximum of Heterocapsa triquetra Ehrenb. at the entrance to the Gulf of Finland. Limnol Oceanogr 48:594-607

Margalef R (1958) Temporal succession and spatial heterogeneity in phytoplankton. In: Buzzati-Traverso AA (ed) Perspectives in marine biology. University California Press, Berkeley, CA, p 323-349

Mouriño C, Fraga F (1985) Determinación de nitratos en agua de mar. Inv Pesq 49:81-96

Peliz A, Dubert J, Santos AMP, Oliveira PB, Le Cann B (2005) Winter upper ocean circulation in the Western Iberian Basin-fronts, eddies and poleward flows: an overview. Deep-Sea Res I 52:621-646

Piedracoba S, Álvarez-Salgado XA, Rosón G, Herrera JL (2005) Short-timescale thermohaline variability and residual circulation in the central segment of the coastal upwelling system of the Ría de Vigo (northwest Spain) during four contrasting periods. J Geophys Res 110: C03018

Pingree RD, Pugh PR, Holligan PM, Forster GR (1975) Summer phytoplankton blooms and red tides along tidal fronts in the approaches to the English Channel. Nature 258: 672-677

Pitcher GC, Boyd AJ, Horstman DA, Mitchell-Innes BA (1998) Subsurface dinoflagellate populations, frontal blooms and

Editorial responsibility: Otto Kinne, Oldendorf/Luhe, Germany the formation of red tide in the southern Benguela upwelling system. Mar Ecol Prog Ser 172:253-264

Reid JL, Mantyla AW (1976) The effect of geostrophic flow upon coastal elevations in the northern North Pacific. J Geophys Res 81:3100-3110

Rines JEB, Donaghay PL, Dekshenieks MM, Sullivan JM, Twardowski MS (2002) Thin layers and camouflage: hidden Pseudo-nitzschia spp. (Bacillariophyceae) populations in a fjord in the San Juan Islands, Washington, USA. Mar Ecol Prog Ser 225:123-137

Rodríguez F, Garrido JL, Crespo BG, Arbones B, Figueiras FG (2006) Size-fractionated phytoplankton pigment groups in the NW Iberian upwelling system: impact of the Iberian Poleward Current. Mar Ecol Prog Ser 323:59-73

Sordo I, Barton ED, Cotos JM, Pazos Y (2001) An inshore poleward current in the NW of the Iberian Peninsula detected from satellite images, and its relation with $G$. catenatum and D. acuminata blooms in the Galician Rías. Estuar Coast Shelf Sci 53:787-799

Tester PA, Steidinger KA (1997) Gymnodinium breve red tide blooms: initiation, transport, and consequences of surface circulation. Limnol Oceanogr 42:1039-1051

Tilstone GH, Figueiras FG, Fraga F (1994) Upwelling-downwelling sequences in the generation of red tides in a coastal upwelling system. Mar Ecol Prog Ser 112:241-253

Torres R, Barton ED (2006) Onset and development of the Iberian poleward flow along the Galician coast. Cont Shelf Res 26:1134-1153

Wooster WS, Bakun A, McLain DR (1976) The seasonal upwelling cycle along the eastern boundary of the North Atlantic. J Mar Res 34:131-141

Submitted: May 15, 2007; Accepted: September 25, 2007 Proofs received from author(s): February 1, 2008 